\title{
HUBUNGAN TINGKAT RELIGIUSITAS DENGAN PERILAKU COPING STRES
}

\author{
Rr. Hartuti Pudji Rahayu \\ Lembaga Penelitian dan Pengembangan Masyarakat
}

\begin{abstract}
INTISARI
Tujuan dari penelitian ini adalah mengelahui tentang hubungan tingkat religiusitas dengan perilaku coping stres. Hipotesis yang diajukan adalah ada hubungan positif antara tingkat religiusilas dengan perilaku coping stres yaitu semakin tinggi tingkat religiusitas seseorang maka semakin baik pula perilaku coping stres. Subjek penelitian adalah mahasiswa dan mahasiswi Fakullas Ekonomi Universitas islam Sullan Agung Semarang berjumlah 100 orang. Analisis statistik yang dipergunakan adalah teknik korelasi parsial jenjang ketiga Hasil analisis data menunjukkan bahwa lidak ada hubungan positif dan tidak signifikan antara tingkat religiusitas dengan perilaku coping stres.
\end{abstract}

Kata kunci: religiusitas, perilaku coping, pengalaman beragama

Rr. Hartuti Pudji Rahayu, lahirdi Salatiga 20 Mei 1970, adalah Staf peneliti pada Lembaga Penelitian dan Pengembangan Masyarakat (LPPM) Semarang. Alumnus Fakultas Psikologi Universilas Kafolik Soegijapranata Semarang tahun 1994 ini juga bekerja sebagai Staf Recruitment and Training Corporate PT. Metro Selular Nusantara Surabaya.

\section{PENGANTAF}

P erubahan-perubahan sosial yang begitu cepat telath membawa perubahan dalam cara berpikir dan pola kehidupan masyarakat. Perubahan itu, jika tidak diikuti kemampuan manusia untuk menyesuaikan diri akan menyebabkan stres di masyarakat.

Banyak orang terpukau dengan modernisasi dan menyangka modernisasi sertamerta akan mengantarkan mereka kepada kesejahteraan. Padahal di balik modemisast terdapat gejala - gejala yang dinamakan agony of modernization atau azab sengsara karena modernisasi. Contoh agony of modemization adalah tidak adanya jaminan sosial, pengangguran, kriminalitas, penyalahgunaan narkotik, zat adiktif dan alkohol. kenakalan remaja, kehamilan remaja, judi, 
prostitusi, perkosaan, gangguan jiwa, dan sebagainya (Idries, 1993).

Gejala-gejala di atas disebabkan oleh meningkatnya intensitas disorganisasi dan disintegrasi sosial di masyarakat. Disorganisasi dan disintegrasi ini terjadi proses perongrongan terhadap agama, moral, budi pekerti, warisan budaya lama, dan tradisional. Hal ini menimbulkan ketidakpastian fundamental di bidang norma, nilai moral, dan etika yang diakibatkan masyarakat kehilangan identitas diri.

Untuk bisa memahami manusia seutuhnya, baik dalam keadaan sehat maupun sakit, pendekatan yang digunakan mestinya tidak lagi memandang manusia sebagai makhluk bio-psiko-sosial (jasmani, psikologis, dan sosial) melainkan manusia sebagai makhluk bio-psiko-sosio-spiritual (jasmani, psikologis, sosial, dan spiritual) (Idries, 1993. Bastaman, 1995).

Dewasa ini terfihat kehidupan beragama pada masyarakat semakin tampak jelas. Mulai banyak bermunculan tempat peribadatan pada tiap-tiap kantor yang semakin lama semakin banyak juga para pegawai yang memanlaatkannya. Pada kaum muda mulai banyak berdiri organisasi keagamaan yang banyak pula peminatnya.

Religius adalah suatu keadaan di mana individu merasakan dan mengakui adanya kekuatan tertinggi yang menaungi kehidupan manusia, dan hanya kepada-Nya manusła merasa bergantung serta berserah diri. Semakin seseorang mengakui adanya Tuhan dan kekuasaan-Nya, maka akan semakin tinggi tingkat religiusitasnya (Dister. 1982). Daradja: (1978) mengemukakan tentang kesadaran agama (religious counsciousness) yang merupakan aspek kognisi dari aktivitas agama dan pengalaman agama (religious experience) yang membawa perasaan pada keyakinan yang dihasilkan oleh tindakan (amaliah). Ditambahkan pula oleh Daradjat (1978) bahwa llmu Jiwa Agama ha- nya mengungkap bagaimana perasaan dan pengalaman orang-orang secara individuil terhadap Tuhan. Tidak selamanya orang mampu menghadapi kesukaran yang menimpanya, dan tidak selamanya pula orang berhasil mencapai tujuannya dengan usaha yang terencana, teratur, dan telah diperhitungkan sebelumnya. Tidak selamanya pula orang berhasil menghindarkan atau menjauhkan hal-hal yang tidak diingininya. Di sini kepribadian sangat menentukan. Jika manusia memiliki kepribadian yang utuh dan jiwa yang sehat, maka la akan menghadapi semua masalah itu dengan tenang. Kepribadian yang di dalaınnya terkandung unsurunsur agama dan keimanan yang cukup teguh, maka masalah yang timbul akan dihadapinya dengan tenang. Akan tetapi orang yang jiwanya goncang dan jauh dari agama boleh jadi ia akan ma rah tan pa sasaran yang jelas atau memarahi orang lain, sebagai sasaran penumpahan perasaan kekecewaan marah, atau sakit hati dan lain sebagainya.

James (dikutip oleh Daradjat, 1978) memberikan definisi agama sebagai berikut: Agama adalah perasaan dan pengalaman Bani Insan secara individual, yang menganggap bahwa mereka berhubungan dengan apa yang dipandangnya sebagai Tuhan. Yang terpenting bagi James adalah pengaruh keyakinan (kepercayaan) itu pada jwa orang yarig bersangkutan dan yang menertukan reaksi terhadap yang dianggapnya Tuhan itu. James tidak memastikan adanya Tuhan tertentu, seperti dalam keyakinan agama-agama Samawi. Maka agama adalah suatu sikap yang diambil seseorang terhadap suatu kebenaran yang Abadi itu yang datang dari perasaan yang mendalam.

\section{TELAAH PUSTAKA}

Perubahan-perubahan sosial yang cepat sebagai konsekuensi modernisasi, kemaju- 
an teknologi dan industrialisasi, mempunyai dampak dakam kehidupan, terutama bagi orang yang tidak dapat menyesuaikan diri dengan perubahan-perubahan tersebut, sehingga pada gilirannya dapat menimbulkan ketegangan, stres, dan lain-lain gangguan jiwa pada dirinya.

Stres dalam anti umum adalah perasaan tertekan, cemas dan tegang (Altman ef af., 1985, h.130). Dalam bahasa sehani-han st res dikenal sebagai stimulus atau respon yang menuntut individu untuk melakukan penyesuaian (Bootzin of al, 1983, h. 481). Biar pun penyesuaian diri individu cukup baik tetapi Wheaton (dikutip oleh Prawirohardjo. 1985, h.121), menyatakan bahwa stres yang datang berlangsung cepat, mendadak, sangat menonjol, dan sering tak dapat dikontrol, sehingga tidak bisa diramalkan atau diinginkan oleh individu tersebut. Begitu pula apabila stres yang akan datang berulangulang dan bertubi-tubi, maka individu tidak berdaya menghadapinya. Individu yang mengalami stres akan mengganggu kehidupan individu tersebut.

Dalam teori st res, konsep copingmerupakan haf yang penting untuk dibicarakan. Konsep coping digunakan untuk menjelaskan hubungan antara slres dengan perilaku individu dalam menghadapi stres. Copingberfungsi untuk menyeimbangkan emosi individu dalam situasi yang penuh dengan tekanan (Solomon, el.al, 1988). Suatu cara yang dilakukan untuk mengatasi situasi atau problem yang dianggap sebagai tanlangan, ketidakadilan atau merugikan maupun sebagai ancaman disebut dengan istilah coping(Lazarus, 1976). Menurut Lazarus dan Launier, copingadalah usaha yang beforientasi pada tindakan intrapsikis untuk mengendalikan atau menguasai, menerima, metemahkan serta memperkecil pengaruh lingkungan, tuntutan internal dan konflik tersebut melampaui kemampuan seseorang (Garmezy dan Rutter, 1983). Shin dkk
(1984) mengatakan bahwa coping adalah usaha untuk mengurangi stres dan tekanan perasaan. Tekanan perasaan ini bisa terjadi karena adanya hal-hal atau masalah-masa. lah yang tidak terpecahkan. Perilaku coping adalah suatu usaha atau tindakan untuk menghadapi situasi yang penuh dengan tekanan atau masalah yang dianggap sebagai tantangan, ketidakadilan, merugikan ataupun mengancam individu baik secara eksternal maupun internal dengan cara mengendalikan, menguasai, menerima, maupun mengurangi dengan reaksi tertentu. Perilaku coping yang dilakukan sangat bervariasi, seperti melakukan rasionalisasi, proyeksi, regresi, kompensasi, alih regresi, melamun, apatis, nostalgia, spesialisasi, pemecahan ideologi. dan resignation. Untuk hal resignation inilah yang akan menjadi pokok permasalahan.

Terdapat pula kenyataan adanya orang dalam masa dewasa awai yang mengalami gangguan-gangguan fisik dan psikologis. Haf yang demikian ini umumnya disebabkan oleh semangat yang kuat untuk bekerja sehingga seseorang bekerja dengan waktu yang berlebihan yang tidak sesuai dengan day a tahan fisik dan psikologis individu tersebut. Banyak di antara ciri penting pada masa dewasa awal merupakan kelanịutan dari ciri-ciri yang terdapat dalam masa remaja. Beberapa di antaranya adalah menunjukkan penonjolan ciri yang membedakan dengan masa kehidupan yang lain, nam. pak dengan adanya peletakan dasar dalam banyak aspek kehidupannya, melonjaknya persoalan hidup yang dihadapinya dibandingkan dengan remaja akhirdan terdapatnya ketegangan emosi.

Dalam hal ini, Becker (Mappiare, 1983) menyatakan bahwa dewasa awal merupakan suatu masa penyesuaian terhadap polapola kehidupan yang baru, dan harapan-harapan sosial yang baru. Manusia dewasa awal diharapkan memainkan peranan-pe- 
ran an baru dalam hal-hal sebagai suami atau steri, orang tua dan sebagai pemimpin rumah tangga, serta mengembangkan sikap-sikap, minat-minat dan nilai-nilai dalam memelihara peranan-peranannya yang baru tersebut.

Sebagai kelanjutan masa remaja, masa dewasa awal memiliki ciri-ciri sebagai berikut:

1. Usia produktif atau "reproductive age"

2. Usia mernantapkan letak kedudukan atau "settling-downage"

3. Usia banyak masalah atau "problem age"

4. Usia tegang dalam hal emosi atau "emotional tension".

Kepuasan atau ketenangan akan dapat dicapai dalam tahun-tahun pertama dewasa awal ini oleh beberapa individu. Tetapi kebanyakan of antaranya tetap mengalami ketegangan emosi sampai mendekati pertengahan masa dewasa awal. Havighurst (dikutip oleh Mappiare, 1983) mengemukakan bahwa seseorang dalam usia awal atau pertengahan tiga puluhan akan dapat memecahkan persoalan-persoalan serta cukup dapat mengendapkan ketegangan emosinya, sehingga seseorang dapat mencapai emosi yang stabil atau kalem. Menurut Becker. harapan-harapan untuk memperoleh status sosial atau jabatan yang terlalu tinggi (tidak sesuai dengan kemampuari) merupakan peluang untuk mendapatkan stres, patah hati yang selanjutnya dapat menimbulkan kekacauan-kekacauan psikologis atau masalahmasalah psikosomatis.

Melihat hal itu semua, tingkat religiusitas pada individu cukup berperanan dalam perilaku coping stres, karena tidak selamanya orang mampu menghadapi kesukaran yang merimpanya, dan tidak selamanya pula orang berhasil mencapai tujuan serta berhasil menghindarkan sesuatu yang tidak diingininya. Usia dewasa awal merupa- kan suatu masa penyesuaian terhadap polapola kehidupan yang baru, sehingga pada usia ini banyak diketemukan individu yang mengalami stres.

\section{HIPOTESIS}

Berdasarkan tinjauan pustaka, telaah teoritik serta permasalahan yang dihadapi, hipotesis yang diajukan adalah ada hubungan positif antara tingkat religiusitas dengan perilaku copingstres, Sernakin tinggi tingkat religiusitas seseorang semakin tinggi pula perilaku copingstres.

\section{METODE}

Sampel penelitian adalah mahasiswa dan mahasiswi Fakultas Ekonomi Universitas Islam Sultan Agung Semarang yang berusaha antara 21 - 35 tahun, beragama Islam dan minimal duduk di semester VIII serta masih aktif kuliah. Adapun pengambilan sampel menggunakan teknik Random Sampling.

Dalam penelitian ini metode yang dipergunakan adalah metode angket yang dipakai untuk mengungkap atau mengukur variabel bebas yaitu tingkat religiusitas, variabel tergantung yaitu perilaku copingstres dan variabel sertaan yang mengukur tipe kepribadian. Selain metode angket, metode lain yang digunakan adalah metode dokumentasi untuk mengetahui usia perkembangan, jenis kelamin, tingkat pendidikan dan agama yang dimiliki subjek penelitian. Angket tingkat religiusitas disusun sebanyak 76 butir yang terdiri dari lima aspek, yaitu aspek Ritual involvement, aspek ideological in volvement, aspek intellectual involvement, aspek Experiential involvement, dan aspek Consequential Involvement yang koefisien reliabilitasnya sebesar 0,912. Untuk angket perilaku coping stres disusun sebanyak 40 butir terdiri dari tujuh aspek, yaitu aspek 
denial, aspek penerimaan, aspek resignation, aspek pelarian diri dari masalah, aspek pengurangan beban masalah, aspek penyalahan diri dan aspek pencarian arti dengan koefisien reliabilitas sebesar 0,910 . Pada angket tipe kepribadian disusun sebanyak 47 butir yang terdiri dari empat faktor, yaitu faktor orientasi terhadap lingkungan, faktor kemampuan menghadapi resiko, faktor pe nyesuaian diri dan faktor pengambilan keputusan yang memiliki koefisien reliabilitas 0,930 .

Pernyataan dari angket tingkat religiusitas terdiri dari pernyataan positif dan pernyataan negatif serta memiliki tiga kemungkinan jawaban dengan sekor bergerak dari 1 sampai 3 untuk negatif dan 3 sampai 1 untuk positif. Pada angket perilaku coping stres memiiiki empat kemungkinan jawaban, yaitu sangat sering, sering, kadang-kadang, dan tidak pernah, sedang sekor bergerak dari 4 sampai 1 untuk positif dan 1 sampai 4 untuk negatif. Untuk angket tipe kepribadian terdapat iima kemungkinan jawaban, yaitu sangat tidak setuju, setuju, ragu-ragu, tidak setuju, dan sangat tidak setuju, sedang sekor bergerak 1 sampai 5 untuk negatif dan 5 sampai 1 untuk positif.

Sesuai dengan hipotesis yang diajukan dan berdasarkan identitas variabel penelitian, jenis data, dan tujuan penelitian yaitu untuk mengetahui hubungan antara tingka: religiusitas dengan perilaku copingstres dengan mengendaiikan tipe kepribadian, usia dan jenis keiamin. maka statistik yang digunakan adalah teknik koreiasi Parsial Jenjang Ketiga.

\section{HASIL}

Perhiturgan analisis menggunakan teknik korelasi Parsiai Jenjang Ketiga, Program SPSS (Statistical Program for Social Soence). Dari hasil analisis tersebut diperoleh hasil $r_{\mathrm{ir}-234}=0,1338$ dengan $p>0,05$.
Dengan demikian dapat dikemukakan bahwa hipotesa penelitian ditolak, sehingga tidak ada hubungan yang positif dan tidak signifikan antara tingkat religiusitas dengan perilaku coping stres.

\section{DISKUSI}

Berdasarkan hasil uji hipotesis, diperoleh hasil bahwa hipotesis yang diajukan ditolak yaitu tidak ada hubungan yang positif antara tingkat religiusitas dengan perilaku copingstres. Dengan demikian tidak terbukti ada hubungan yang positif antara tingkat religiusitas dengan perilaku coping stres yaitu semakin tinggi tingkat religiusitas maka belum tentu pula semakin baik perilaku coping stres yang diiakukannya. Dengan kata lain faktor religiusitas kurang mempunyai peranan dalam perilaku coping stres. Kemungkinan masih ada faktor-laktor lainnya yang lebih berpengaruh pada perilaku coping stres.

Faktor-faktor yang kiranya berpengaruh lebih besar pada perilaku coping stres selain tingkat religiusitas adalah sebagai berikut:

\section{Pertama, tingkat pendidikan}

Pendidikan yang tinggi akan mempengaruhi perilaku coping stres individu. Hal ini disebabkan karena pendidikan memungkinkan individu untuk mampu memandang suatu masalah secara lebih realistis dan sistem pemecahannya lebih etektif. Keyakinan diri, pemikiran rasional, dan penilaian terhadap suatu masalah merupakan hasil dari kognisi yang diperoleh selama seseorang mengikuti proses pendidikan. Hal ini sesuai dengan teori yang dikemukakan oleh Billings dan Moos (1984) yang menyebutkan bahwa tingkat pendidikan yang tinggi yang dimiliki oleh individu akan mengakibatkan perkembangan kognitif yang lebih komplek dan tinggi. Pada penelitian ini, subjek pene- 
litian adalah mahasiswa, sehingga dapat dikatakan bahwa perilaku coping stres yang tampak adalah wajar dengan tingkat religiusitas yang tinggi. Jadi dapat disimpulkan bahwa tingkat pendidikan sangat berpengaruh dalam perilaku copingstres.

\section{Kedua pengalaman}

Pengalaman merupakan bahan acuan atau perbandingan individu dalam menghadapi suatu kejadian yang hampir sama. Apabila pengalaman itu mengesankan atau sesuai dengan individu, maka individu tersebut akan menggunakan pengalaman di saat menghadapi situasi yang hampir sama. Te tapi apabila pengalaman itu kurang atau tidak mengesankan, maka individu akan mencari bentuk baru lagi apabila menghadapi situasi yang sama, atau membuang pengalaman tersebut. Dalam penelitian ini, subjek yang berusia dewasa awal ini telah mempunyai pengalaman dalam melakukan perilaku coping stres pada masa perkembangan sebelumnya. Hal ini sesuai dengan teori Law of Exercise yang dikemukakan oleh Thorndike (Soemanto, 1990), yatu makin banyak dipraktekkan atau digunakannya hubungan stimulus respon, makin kuat hubungan itu.

\section{Ketiga, kebuday aan setempat}

Kebudayaan dapat berpengaruh dalam perilaku manusia. Pada penelitian ini, subjek diambil dari masyarakat Jawa, yang dengan kekhasannya, yaitu bersikap "sabar, nrima, sumeieh pada Yang Memberi Hidup, dan percaya bahwa itu semua memang harus dikerjakan". Menurut Hardjowirogo (1989), kurang benar jika orang terus saja mengeluh kalau nasibnya tidak baik. Menerima (nrima) berarti tahu tempatnya sendiri, berarti percaya pada nasib sendiri dan berterma kasih kepada Tuhan karena kepuasan dalam me- menuhi apa yang menjadi bagiannya dengan kesadaran bahwa semuanya telah ditetapkan (Mulder, 1985). Kemudian cenderung bersikap tutup mulut, berdiandiri, dan akhirnya melakukan mawas diri dengan jalan menelaah hati nurani (Hardjowirogo, 1989). Hal ini kemudian tampak pada hasil penelitian ini, subjek yang termasuk dalam masyarakat Jawa, melakukan perilaku coping stres dengan wajar, bahkan cenderung untuk bersikap seolah-olah tidak mengalami stres.

\section{Keempat, usia}

Usia subjek pada penelitian ini adalah 21 sampai 35 tahun, yang terkategori dalam masa dewasa awal. Usia sangat berpengaruh dalam berperilaku coping stres karena pertambahan usia selalu disertai dengan bertambahnya kemampuan individu dalam cara berpikir, cara menyerap nilai-nilai kehidupan, dan cara penyesuaian diri (Biren dan Schale, 1977). Pada masadewasa awal, individu mengalami perkembangan kognisi yang baik sehingga mempengaruhi cara berpikir, cara menyerap nilai-nilai kehidupan, dan cara penyestaian diri, apabila dibandingkan dengan masa-masa perkembangan sebelumnya, sehingga dapat mempengaruhi perilaku copingyang dilakukannya.

\section{PENUTUP}

Berdasarkan hasil penelitian yang telah dilakukan dapat disimpulkan bahwa semakin tinggi tingkat religiusitas yang dimiliki oleh individu yang bersangkutan, maka belum tentu perilaku copingstres yang dilakukannya pun semakin baik.

Adapun faktor-faktor lainnya yang kiranya lebih berpengaruh terhadap perilaku coping stres individu dalam penelitian ini adalah: Tingkat pendidikan, pengalaman, kebudayaan setempat, usia. 
Saran yang dapat dikemukakan oleh peneliti sehubungan dengan hasil penelitian adalah sebagai berikut:

Pertama, penelitian ini dapat menjadi acuan pada penelitian-penelitian yang membahas perilaku coping stres, yaitu bahwa masih ada faktor-laktor yang lebih berpengaruh pada perilaku coping stres apabila dibandingkan dengan faktor tingkat religiusitas seperti: faktor usia, laktor tingkat pendidikan, faktor pengalaman, dan faktor kebudayaan setempat. Dari keempat faktor tersebut dapat dicoba dicari hubungannya dengan perilaku copingstres individu. Misalnya dengan meneliti perbedaan antara masa remaja awal dengan remaja akhir, perbedaan antara tingkat pendidikan SMA dengan tingkat pendidikan SD atau perbedaan antara kebudayaan yang satu dengan yang lainnya, dengan perifaku copingstres yang dilakukan individu tersebut. Sedangkan faktor tingkat religiusitas individu tersebut dapat diabaikan.

Kedua, sedangkan untuk proses konseling, faktor tingkat religiusitas individu tersebut juga dapat diabaikan. Walaupun begitu konselor dapat menyarankan pada klien bahwa religiusitas yang dimilikinya itu dapat membantu klien dalam hal ketenangan psikis, tanpa mempengaruhi klien tersebut dalam melakukan copingstres.

\section{DAFTAR PUSTAKA}

Altman, S. Valwnsy, E \& Hodgets, A. 1985. Organizational Behavior: Theory and Practice. New York: Academic Press. inc.

Bastaman, H.D. 1995. Integrasi Psikologi dengan Islam. Cetakan Kedua, Cetakan Kedua. Editor: Fuad Nashori. Yogyakarta: Yayasan Insan Kamil\& Penerbit Pustaka Pelajar.
Billing, A.G. dan Moos, R.H. 1984. Coping, Stres, and Social Resources Among Adult with Unipolar Depression. Journal of Personality and Social Psychology. Volume 46.

Biren, J.E. and Schale, K.W. (edit). 1977. Handbook of The Psychology of Aging. New York: Litton Educational Publishing inc.

Bootzin, R. R, Loftus, E.F. and Zajonc, R.B. 1983. Psychology Today An Introduction. New York: Randsun House.

Daradjat. 1978. Ilmu Jiwa Agama. Jakarta: Penerblt Bulan Bintang.

Dister, N. S. 1982. Pengalaman dan Motivasi Beragama, Pengantar Psikologi Agama. Jakarta: Lembaga Penunjang Pembangunan Nasional (Leppmas).

Garmezy. N. and Ruttler, M. 1983. Strees, Coping and Development in Children. New York Mc. Graw-Hill Book Company.

Hardjowirogo, M. 1989. Manusia Jawa. Jakarta: CV. Haji Masagung.

Idries, 1993. Agama Obat Penyembuh Jiwa. Jakarta: Tabloid Jumat.

Lazarus, R.S. 1976. Pattern of Ad,iusment. Tokyo: Mc. Graw-Hill Kogaluska, LTD.

Mappiare, A 1983. Psikologi Orang Dewasa. Surabaya: Usaha Nasional.

Mulder, 1985. Pribadi dan Masyarakat of Jawa. Jakarta: Sinar Harapan.

Prawirohardjo. 1985. Stres Tinjauan Dar Se$g$ Fisik dan Sosio Budaya. Semarang: Yayasan Widya Dharma.

Shin, M., Rosano, M.,Morch, H., Chest Nut, D.E. 1984. Coping With Job Strees and Burnout In The Human Service. Journal of Personality and Social Psychology. Vollume 46. Nomor 4. 
Soemanto, 1990. Psikologi Pendidikan. Jakarta: Renika Cipta.

Solomon, Z., Mario, M. and Avit Zur, E. 1988. Coping, Locus of control, Social
Support, and combat related Post traumatic Stres Disorder: A Prospective Study. Joumal of Personality and Social Psychology. Volume 55. Nomor 2. 